\title{
INFORMAL EMPLOYMENT AND QUALITY OF LIFE IN RURAL AREAS OF UKRAINE
}

\author{
Marcela Chreneková, Katarína Melichová, Eleonóra Marišová, Serhiy Moroz
}

Received 18 February 2016; Accepted 30 June 2016

\begin{abstract}
Informal economy is rather difficult to define and demarcate in the methodological context. International Conference of Labour Statisticians in 2003 adopted a set of guidelines regarding definition of statistical categories of informal employment. These include for example employed unregistered own-account workers, contributing family workers, persons who work based on oral agreement, etc. Informal economy is a contentious topic in many developing countries as it brings about many elements that from several aspects adversely affect the development. The most commonly stressed are the fiscal implications (associated with tax revenue loss) and some social concerns. However, in some parts of the world informal sector went from being considered as a negative occurrence to be tolerated as a partial solution to some of the challenges that hinder development of rural regions and communities. The aim of the paper is to determine the relationship between informal economy and level of development and quality of life in Ukrainian regions. The paper examines the role of informal economy in regional structure of Ukraine, while confronting the findings with regional divergence in relevant indicators of development and quality of life. There are statistically significant differences in the size of the informal employment among different types of Ukrainian regions (by rural-urban typology). With increasing share of informal employment in the regions, the income level of households decreases significantly even when we take into consideration the level of unemployment.
\end{abstract}

Key words: informal employment, quality of life, regional disparities, rural economy, Ukraine

Анотація: Неформальну економіку досить важко визначити та розмежувати в методологічному контексті. На Міжнародній конференції статистиків праці у 2003 р. був прийнятий перелік вказівок, що стосуються визначення статистичних категорій неформальної зайнятості. До них відносяться, наприклад, самозайняті незареєстровані працівники, працівники сімейних підприємств, особи, які працюють на основі усної угоди тощо. Неформальна економіка є спірним питанням в багатьох країнах, що розвиваються, оскільки вона спричиняє появу багатьох елементів, які з різних аспектів негативно впливають на розвиток. Найбільш часто підкреслюються фріскальні наслідки (пов'язані з втратою податкових надходжень) та деякі соціальні проблеми. Проте в деяких частинах світу сприйняття неформального сектору змінилося

\footnotetext{
${ }^{1}$ Ing. Marcela Chreneková, PhD., Ing. Katarína Melichová, PhD., Prof. JUDr. Eleonóra Marišová, PhD., Serhiy Moroz, Faculty of European Studies and Regional Development, Slovak University of Agriculture Nitra, A. Hlinku 2; e-mails: marcela.chrenekova@uniag.sk; katarina.melichova@is.uniag.sk; eleonora.marisova@uniag.sk; smorozmail@gmail.com
} 
з негативного до толерантного, як часткового вирішення деяких проблем, що заважають розвитку сільських територій та громад. Метою статті є визначення взаємозв'язку між неформальною економікою та рівнем розвитку та якістю життя у регіонах України. У статті аналізується роль неформальної економіки у регіональній структурі України, яка зіставляється 3 висновками щодо регіональної диференціації відповідних показників розвитку та якості життя. Існують статистично значущі відмінності у розмірах неформальної зайнятості серед різних типів регіонів України (за сільсько-міською типологією). Зі збільшенням частки неформальної зайнятості у регіонах рівень доходів домогосподарств значно зменшується, навіть якщо ми приймаємо до уваги рівень безробіття.

Ключові слова: неформальна зайнятість, якість життя, регіональні диспропорції, сільська економіка, Україна

\section{Introduction}

Quality of life is from the perspective of sociology associated with standard of living, which includes material and economic conditions to meet basic needs. Economic dimension of quality of life reflects aspects determined by economic performance, material wealth, material needs, income etc.

Life quality and living standard of individuals and households is directly affected by conditions of place or region where they live. Geography and regional studies consider the quality of life in context of a particular territory at different regional levels, and combine objective and subjective views. Objective side constitutes living conditions, subjective is understood as experience of these aspects. There are several concepts of quality of life. Its practical level is currently being examined.

European Commission, under the new Europe 2020 strategy, in the pursuit of social inclusion monitors contact with the labor market as unemployment does not mean only fail or decrease of income but it brings also other social and psychological consequences. Both situations may reduce the quality of life of individuals and households.

\section{Theoretical background}

Majority of working scenarios include working for one company and having some type of working agreement, set salary, agreed stable location or locations, regular working time and some type of taxes and security contributions. Informal work, on the other hand, is defined as informal arrangement with an employer or in irregular self-employment occupation. According to International Labour Organization (ILO, 2004), informal employment comprises jobs carried out in formal and informal sector enterprises or households. Informal economy includes barter of goods and services, mutual self-help, odd jobs and direct sale activities. Income generated by the informal economy is usually not recorded for taxation purposes, and is often unavailable for inclusion in gross domestic product computations. Work within informal economy is often remunerated without payment of employment and social security. For dependent employees informal employment relationship can be voluntary or involuntary (Dohmen et al., 2010). The informal jobs or activities can be registered or not (Lehnamann et al., 2012).

The phenomenon of informal work, until a few years ago, implied talking about the developing world, but developed economies are also facing the issue (Harvard Business Review, 2012). The informality is driven both by employers and employees. Employers tend to pay lower wages, less or no benefits, and hire workers only in case of need (Zimmermann, 2012). Workers, on the other hand, prefer informal working situations because it gives them freedom and flexibility to pursue multiple interests. Another reason is lack of ability to find a formal work. In the situation of economic decline and structural change informal work means more flexibility for both sides. 
Informal employment has consequences on quality of life. It can be considered from two different points of view. One of them is lifetime earning potential. Workers who begin their working lives on temporary or short-term contracts start out at lower wages, which lowers their earning potential (Zimmermann, 2012), standard of living and quality of life. Households which depend on informal employment income are likely to have substantially higher poverty risk (Chen et al., 2006). In the situation of lack of income and deprivation can, on the other hand, informal work help to raise the quality of life of households and communities.

Data collection efforts show for a growing number of countries, where the share of the informal economy is higher in rural areas and higher in agricultural than in non-agricultural activities (ILO, 2012).

Before transition, countries of the CIS region were characterized by employment for everybody and considerable wage compression and a quite egalitarian distribution of income (Münich et al., 2005). This started to change in early 1990s (Brown et al., 2006). Kupets (2006) provided first evidence of the determinants of relatively high unemployment rates in rural areas of Ukraine in the period 1997-2003.

Material comfort and material well-being, employment and social security are important components of quality of life (Ira, Michálek and Podolák, 2005; Laluha et al. 2005). These are, according to the EU statistical office, most commonly expressed by indicator of household income and average monthly wage.

Report of the European Commission on Measurement of Economic Performance and Social Progress (Stiglitz, Sen, Fetoussi, 2009) also refers to material circumstances (income, expenditure, assets) and recommends paying attention to the search for indicators measuring the distribution of income and the overall issue of the functioning of private households.

Quality of life and quality of living conditions, especially in rural areas, are studied in last decades (D'Agostini and Fantini, 2008). Social and economic problems of Ukrainian countryside during and after transition are described (Pisarenko, 1999, Macour and Swinnen, 2007). Main reason of the situation is high rate of unemployment leading to migration to another region or country (Kowalska and Puchała, 2015) which, in the other hand, cause depopulation of deprived regions and the countryside, aging of the population or rural poverty (Pantyley, 2009, Kozelová et al., 2011, Semenova, 2012, Knapik and Kowalska, 2014). Informal employment can be the most effective means to rise out of poverty (ILO, 2013). Several authors proved role of informal economy in viability of rural regions (Thomka, 2005). Informal work is, in some countries, tolerated as a partial solution to some of the challenges that hinder development of rural regions and communities.

The joint measurement and analysis of employment and household income is relevant to understanding the relationship between being poor and working in informal employment (Chen et al., 2006). Informal activity in the underground Ukrainian economy plays an important role (Lehnamann et al., 2012). The aim of the paper is to determine the relationship between informal employment and objective and subjective indicators of quality of life in Ukrainian regions.

\section{Material and methods}

Methodology was conceptualized in order to answer three research questions: What regional disparities in level of development exist in Ukrainian regions? Are there differences in informal employment in rural-urban context and what are the basic characteristics of informal sector in rural regions of Ukraine? What is the relationship between informal employment and selected indicators of quality of life in Ukrainian regions?

We have examined household income and living conditions, and labour market in regions of Ukraine. Special attention was paid to informal employment in rural areas. Relationship between informal employment and quality of life was analysed from objective perspective (using wage and overall and rural unemployment as indicators) and subjective perspective (using households' perceptions of their deprivation as indicators). 
There are a number of definitions of informal employment. We used definition adopted by the $17^{\text {th }}$ International Conference of Labour Statisticians in 2003 and used by International labour organization (ILO). According to this definition, informally employed include the following categories of the employed population: employed at enterprises of informal sector (unregistered own-account workers, employers and their wage workers, contributing family workers, etc.); contributing family workers at enterprises of formal sector; employees who work at informal work places of formal sector (persons who worked according to oral agreement or did not have any social guarantees, particularly no single contribution for compulsory state social insurance, without right to annual leave and paid sick leave).

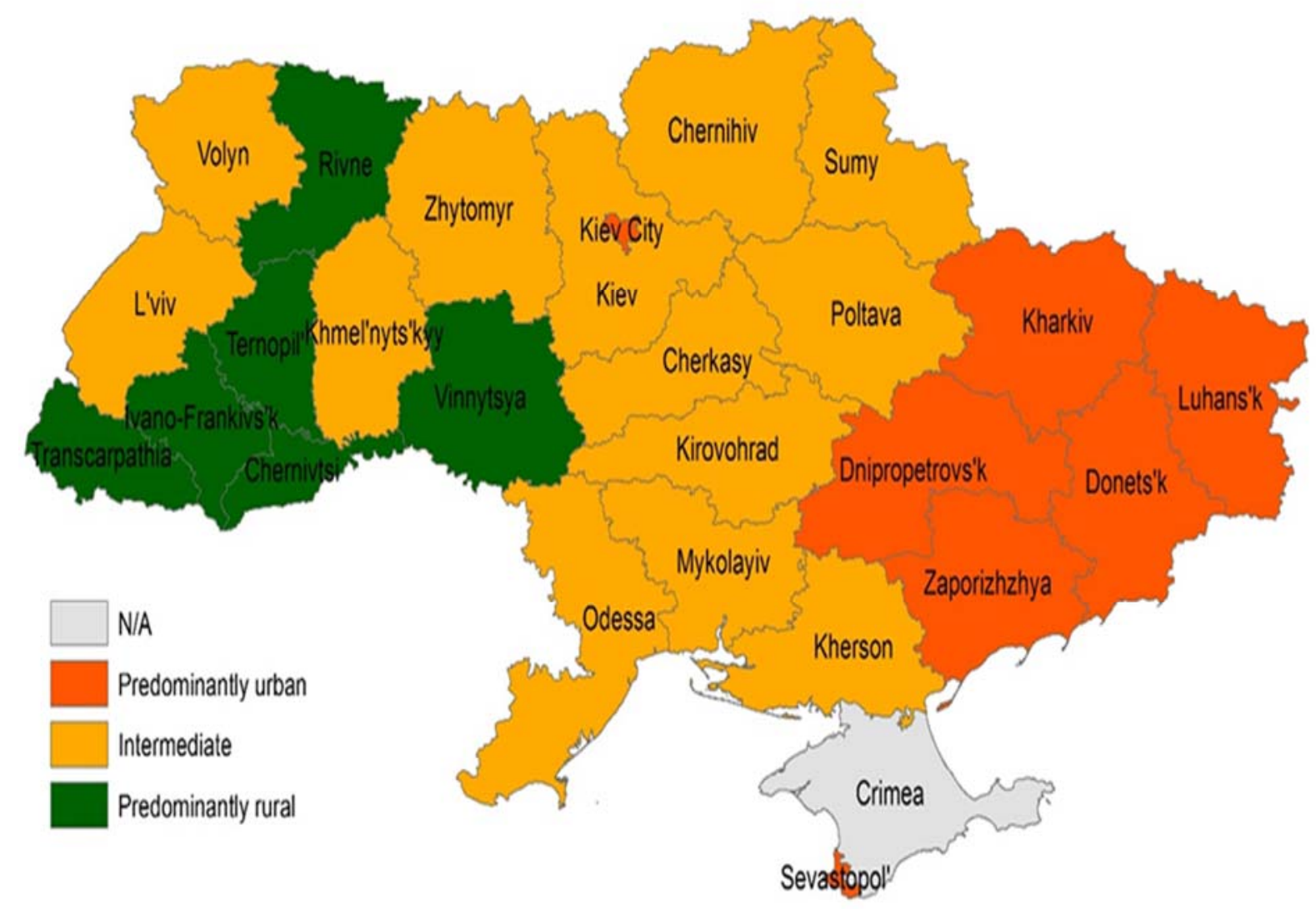

Fig 1. Rural-urban typology of Ukrainian regions. Source: own elaboration based on data of State Statistics Service of Ukraine (2015).

In our research, we used datasets of demography, income and living conditions, household income in regions and labour market held by State Statistics Service of Ukraine. Information on unemployment is based on results of sampling survey population of economic activity (according to ILO methodology). These data differ greatly (are 4.5 times higher for urban settlements and 3.2 times higher for rural settlements) from those that are based on registered unemployment. Data from the sampling survey are closer to reality.

We focused on regional disparities in the share of informal employment in formal and informal enterprises. Given that it was found that the share of informal employment does not have a normal distribution, when analysing regional disparities in the context of this variable we reached for nonparametric statistical tests. In addition to violation of normality, extreme values that occur in the dataset also pose a methodological problem. Since the elimination of extreme values would cause a significant loss of information, Kruskal-Wallis median test was applied, which is robust against the occurrence of extreme values.

In order to reveal the relationship between the informal employment and quality of life, a number of selected indicators were used: average monthly wage in PPP and unemployment rate - to quantify the objective dimension of quality of life, self-perception of households of their income and material welfare - to quantify the subjective dimension of quality of life. Cross-sectional (spatial) data from a single year (2014) were used. 


\section{Regional development disparities in Ukraine}

Regional disparities among Ukrainian regions are manifold, both on regional level, as well as between the urban centres of individual regions and their hinterlands. According to the State Statistics Service of Ukraine (2015) economic activity in 2008-2014 period decreased in almost all regions of Ukraine. The average (monthly) economically active population aged 15-70 years in 2014 decreased by $4.3 \%$ as compared to 2013 . Average economic activity rate of population in $2008-2014$ was $64 \%$ on the national level. This indicator ranged from $66.14 \%$ to $58.15 \%$ on the regional level in the same period. Excluding city of Kiev and city of Sevastopol, the highest values of the indicator were identified in Chernigivska and Dnipropetrovska region and lowest in Ivano-Frankivska and Ternopilska regions. The decline of this indicator was observed mainly among the dwellers of rural areas.

We can observe significant regional disparities in Ukraine in the level of income measured as average monthly wage per capita (data for Crimea are not available). There is a clear WestEast polarisation, where the most Eastern regions, namely Dnipropetrovsk and Donetsk regions as well as their neighbouring regions reach higher values of this indicator. In contrast, rural regions localised in the South-West part of the country reach average and below average income levels. On average, only the population living in capital city earns more than 400 euros per month. This polarisation indicates the importance of rural-urban character of specific regions. Although Eastern regions of the country are affected by current political situation in this part of the country, the level of urbanisation of the regions in question (higher number of larger urban settlements) and their industrialisation level positively affects the income level of population living there. Significant portion of the rural population in these regions is forced to find jobs outside their rural settlements, in large industrial cities. However, this approach will not solve the problem of rural unemployment effectively.

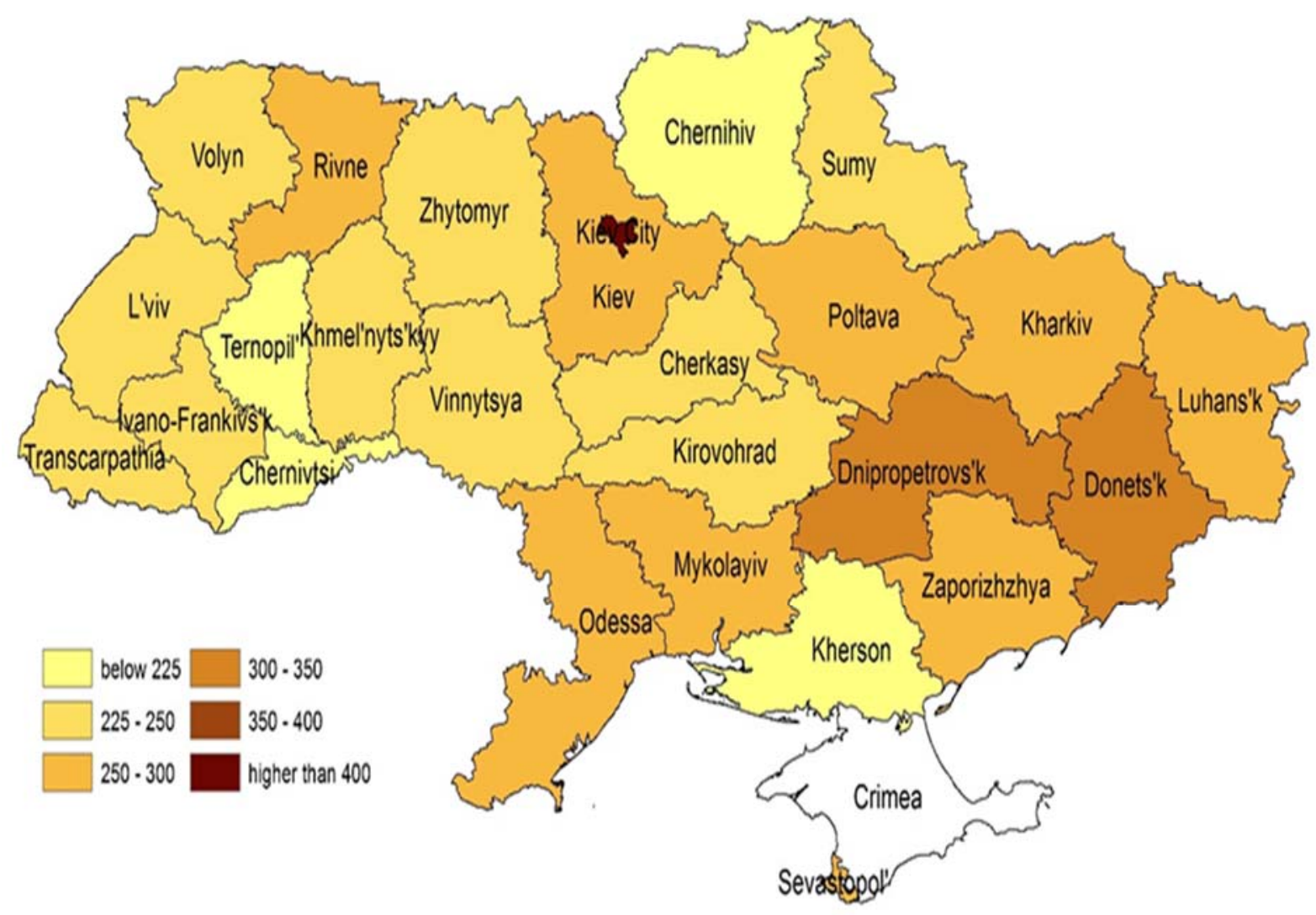

Fig 2. Average monthly wage (euros in PPP) in Ukrainian regions in 2014. Source: authors' own elaboration based on data of State Statistics Service of Ukraine (2015)

Unemployment rate in 2008-2014 period reflected situation after the world economic crisis with its maximum in 2009 and minimum in 2013. Average unemployment rate increased from $7.3 \%$ 
to $10.2 \%$ in the last year of the period, with probable further increase. Unexpectedly, the regional disparities in level of unemployment do not correspond to the regional disparities identified in income level. The Eastern regions of Ukraine (along with some Northern regions) reach the highest values of overall unemployment rate fluctuating around $11 \%$. Predominantly rural and intermediate regions in the South-West part of the country (besides the capital and its surrounding) had lowest unemployment rate in 2014. Significant finding is that predominantly rural regions, namely Transcarpathia, Ternopil and Ivano-Frankivsk show lower rate of unemployment in their rural parts then the overall unemployment rate. Rural population in these regions is more active in terms of establishment and development of business entities (partly due to the close location to EU countries). This is also the case in several intermediate regions (Kherson, Cherkasy), which also seems to be connected with higher entrepreneurial activity in rural areas of these regions. In contrast, the largest predominance of rural unemployment (when we take into account the overall level of unemployment in the region) was identified in the most urbanised regions in the Eastern part of the country. Heavy industrialization efforts funded by the government leave rural settlements in these regions increasingly lagging behind with very limited job opportunities.

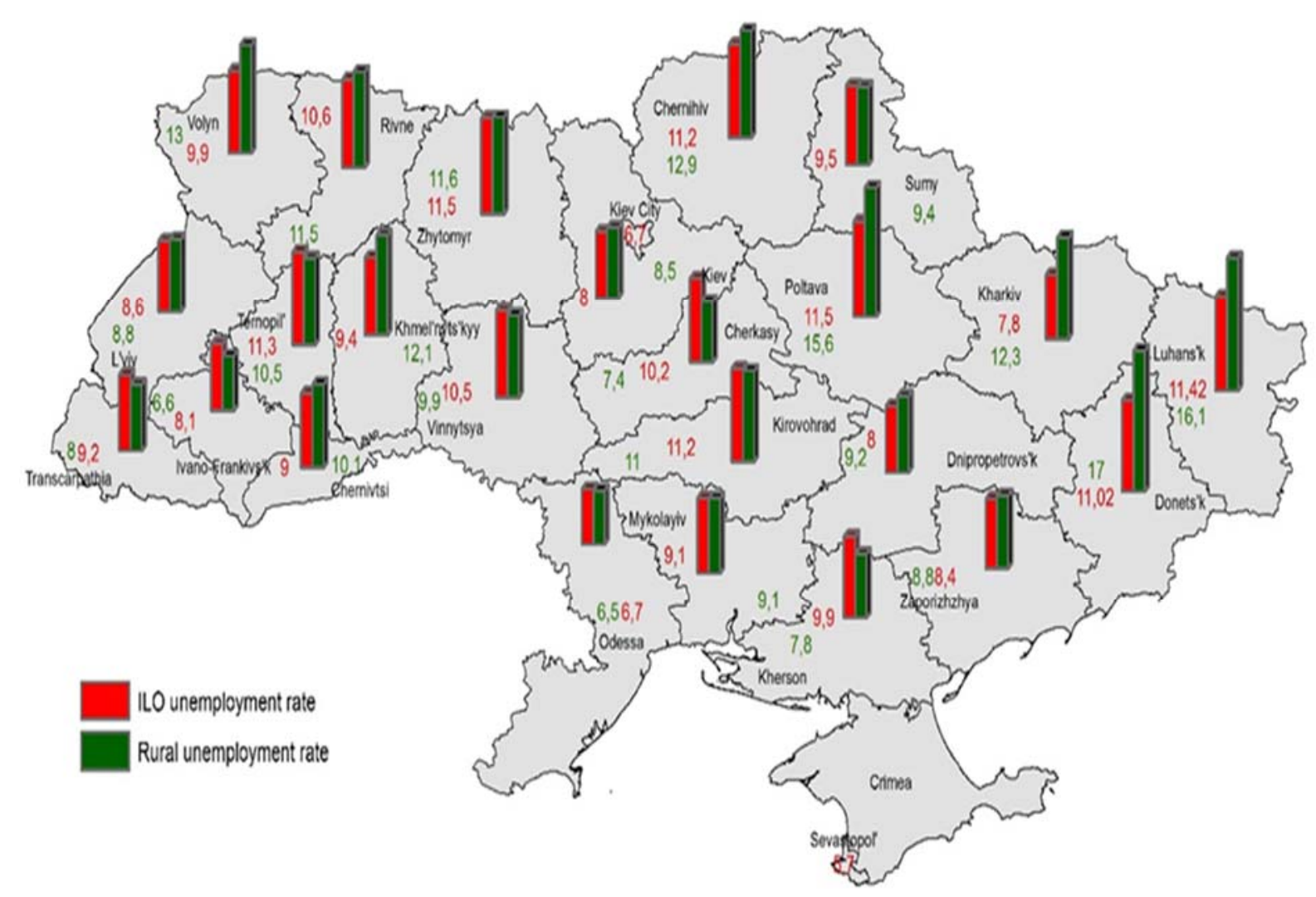

Fig 3. Ukraine: unemployment rates according to regions. Source: own elaboration based on data of State Statistics Service of Ukraine (2015)

We have also examined unemployment rate according to occupations and type of economic activity. From total amount of unemployed, the highest rate of unemployment is seen in skilled workers using specific tools working in industry and wholesale and retail trade and repair of motor vehicles and motorcycles. Considering unemployed population living in rural areas, the highest unemployment rate was in elementary occupations and plant and machine operators and assemblers in agriculture. 


\begin{tabular}{|c|c|c|c|c|c|c|}
\hline & \multicolumn{2}{|c|}{ Employed population } & \multicolumn{3}{|c|}{ Formal enterprises } & \multirow{2}{*}{$\begin{array}{l}\text { Informal } \\
\text { enterprises }\end{array}$} \\
\hline & $\begin{array}{c}\text { Formal } \\
\text { employment }\end{array}$ & $\begin{array}{c}\text { Informal } \\
\text { employment }\end{array}$ & Total & $\begin{array}{c}\text { Formal } \\
\text { employment }\end{array}$ & $\begin{array}{c}\text { Informal } \\
\text { employment }\end{array}$ & \\
\hline Total & 74.9 & 25.1 & 86.7 & 86.4 & 13.6 & 13.3 \\
\hline Women & 78.0 & 22.0 & 88.4 & 88.2 & 11.8 & 11.6 \\
\hline Men & 72.0 & 28.0 & 85.0 & 84.7 & 15.3 & 15.0 \\
\hline Urban & 82.5 & 17.5 & 95.3 & 86.5 & 13.5 & 4.7 \\
\hline Rural & 56.6 & 43.4 & 65.9 & 85.9 & 14.1 & 34.1 \\
\hline
\end{tabular}

Tab 1. Formal and informal employment. Source: State Statistics Service of Ukraine, 2015

Higher share of those who are employed informally occurred in rural areas $(43.4 \%$ from total rural employment) if compared to towns and cities $(17.5 \%$ from total urban employment) in 2014. Also more informal employment was created in informal enterprises $(79 \%$ from total informal employment) located in rural areas in comparison to urban in 2014.

Informal employment has been concentrated in certain sectors and social and economic groups. According to employment status, informal labour relations prevailed in self-employment sector where a share of informally employed population has amounted to $72.7 \%$ and among the gainfully employed these persons have reached $16.1 \%$. Of total rural self-employment, 92.9\% persons were employed informally.

According to occupations, informal labour is most often occurred in elementary occupations (65.4\%). Of informally employed classified under elementary occupations a significant share has been living in rural areas (79.9\%). Close to one third of all services and trade personnel (22\% men and $34.5 \%$ women), skilled workers in agriculture, forestry and fish farming $(43.1 \%$ men and $15.5 \%$ women) and skilled workers using specific tools (32.5\% men and $21.7 \%$ women) were employed informally.

Men as compared to women have been more inclined to informal work (57.7\%). Analysis of informal employment by age group shows that its highest level is characteristic for persons 1524 years old $(33.2 \%)$ and those $60-70$ years old $(41.1 \%)$. These categories of the population are most vulnerable and socially unprotected. Among the informally employed population, over two thirds $(68.3 \%)$ were persons who had acquired vocational, complete secondary or incomplete tertiary education. In case of informally employed women complete secondary education dominated, followed by vocational and incomplete higher education. Informally employed men were educated in vocational followed by complete secondary education. Among the officially employed population, the persons with tertiary education dominated $(61.6 \%)$.

From all informal sector enterprises in rural areas, $83.3 \%$ operate in agriculture, forestry and fishery and $9.2 \%$ in construction. A significant share of informally employed persons has been engaged into agriculture, forestry and fishery. ILO also stated higher informal employed in agricultural than in non-agricultural activities (ILO, 2012). Other widespread types of economic activity for the population of this category are as follows: wholesale and retail trade and construction (figure 2). Population employed informally in rural formal enterprises has been mostly engaged into wholesale and retail and repair of motor vehicles (31.2\%) agriculture, forestry and fishery (21.7\%) and construction (18.9\%). 


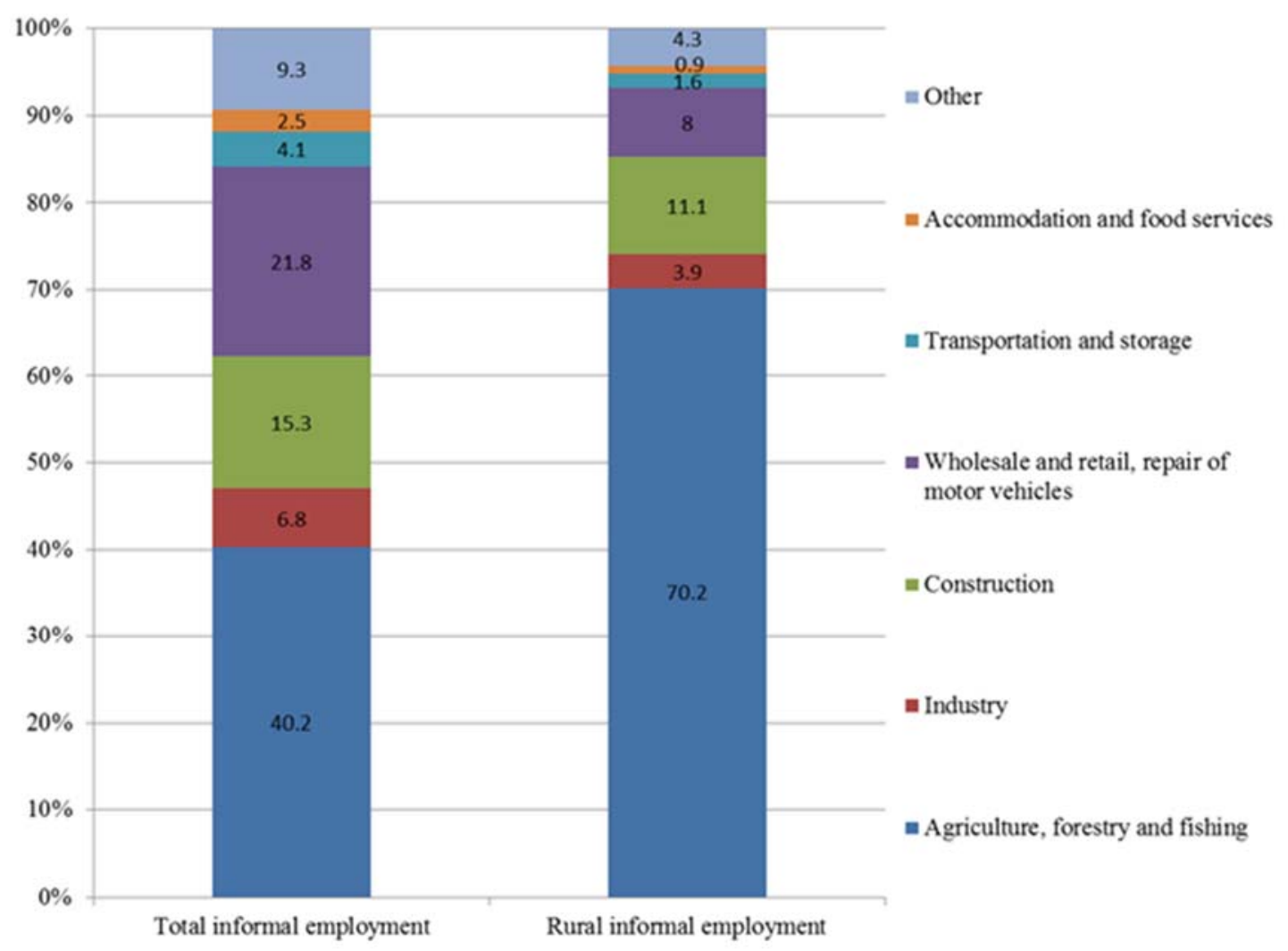

Fig 4. Informal employment rate by type of economic activity in Ukraine in 2014. Source: State Statistics Service of Ukraine, 2015

\section{Regional disparities in the share of informal employment}

There are statistically significant differences in the share of informal employment not only between rural and urban settlements but also on the regional level in the context of rural-urban typology. From the total number of 27 regions in Ukraine, only 24 were considered in this stage of the analysis (cities of Kiev and Sevastopol, as well as Crimea region were excluded due to the unavailability of certain indicators as well extreme values that these regions reached in others).

\begin{tabular}{|c|c|c|}
\hline Rural urban typology & Sample Size & Average Rank \\
\hline Predominantly urban (1) & 5 & 5.2 \\
\hline Intermediate (2) & 13 & 11.31 \\
\hline Predominantly rural (3) & 6 & 21.17 \\
\hline
\end{tabular}

$$
\text { Test statistic }=14.71 \quad \text { P-Value }=0.000638765
$$

Tab 2. Kruskal-Wallis test for share of informal employment by rural-urban typology. Source: own elaboration based on data of State Statistics Service of Ukraine (2015)

We tested the null hypothesis that the median share of informal employment within each of the three types of regions is the same. As the statistically significant value of the Kruskal-Wallis test statistic indicates there are statistically significant differences in the size of the informal employment among different types of Ukrainian regions. 


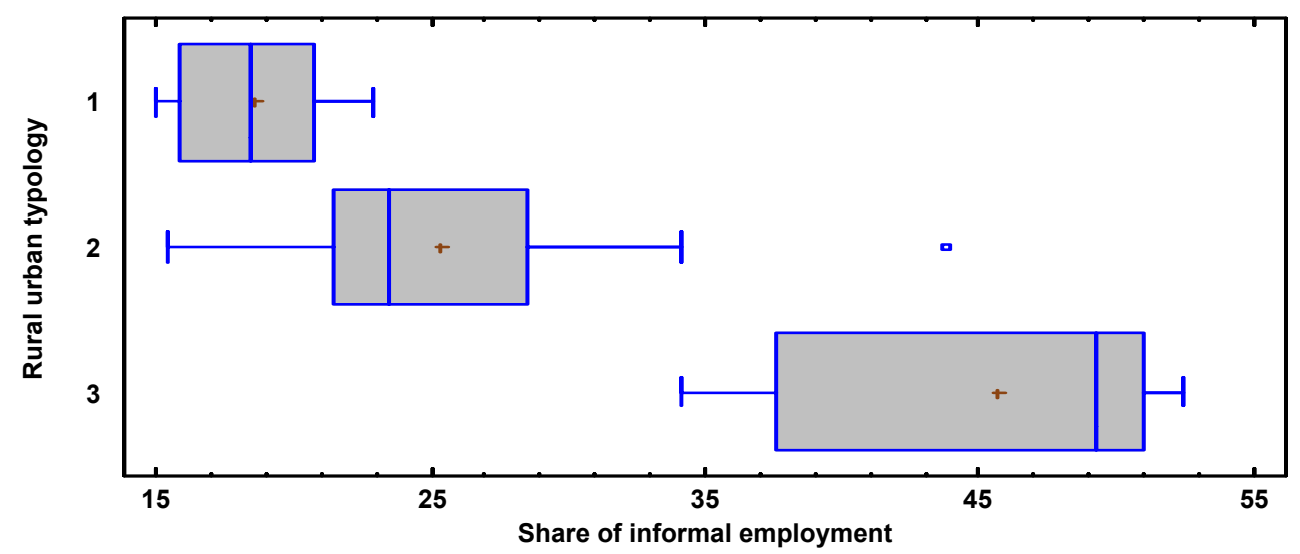

Fig 5. Regional disparities in the share of informal employment ( 1 - predominantly urban, 2 - intermediate, 3 predominantly rural). Source: own elaboration based on data of State Statistics Service of Ukraine (2015)

Based on the Box-and-Whisker Plot depicted above, we can conclude that there is a positive relationship between the share of the informal employment and the increasing degree of rurality on the regional level, with predominantly rural regions characterised by the largest share of informal employment. ILO collection efforts also prove higher share of informal economy in rural areas (ILO, 2012). However, there is a highest level of variability in the context of share of informal economy in this category. This could be caused by a different composition of the regional economy, their relative position towards a significant growth pole etc.

\section{Informal employment and quality of life in Ukrainian regions}

Relatively unfavourable relationship was identified between the level of informal employment and several selected indicators of quality of life in 24 Ukrainian regions (indicators quantifying both objective dimension of quality of life and subjective, i.e. perceived aspects of quality of life).
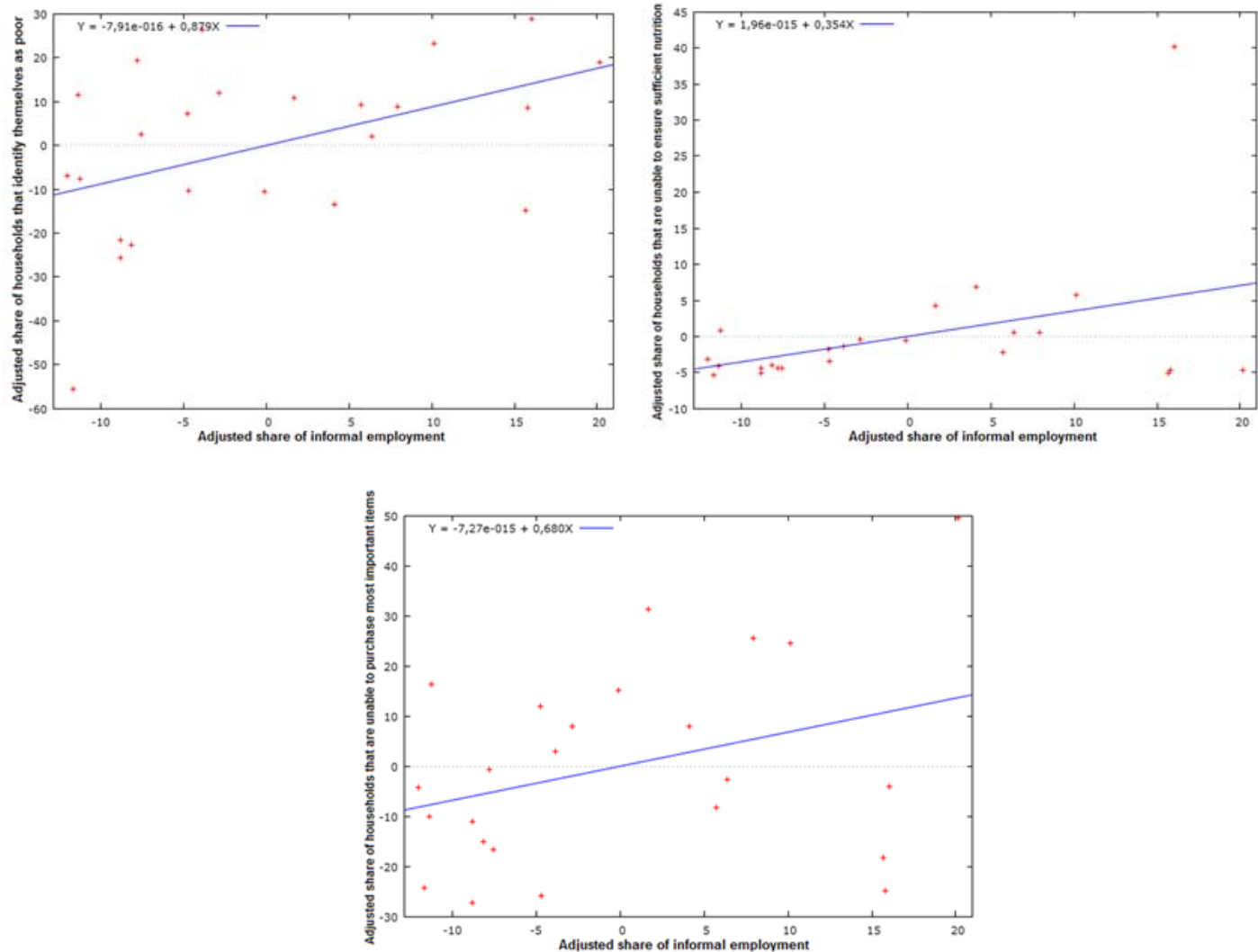

Fig 6. Relationship between the share of informal employment and selected indicators of subjective quality of life in 2014 (adjusted according to the level of disposable income of households). Source: own elaboration based on data of State Statistics Service of Ukraine (2015) 
On the regional level, there is a positive correlation between the share of population employed informally and share of households that perceive themselves as not able to ensure even sufficient level of nutrition, while this relationship with the share of households that described themselves as unable to purchase the most important items in the consumer basket is even stronger. This relationship is apparent even if we control for the regional differences in the level of disposable income that we can expect to significantly affect the perceived quality of life of population as can be seen from the charts depicted above. The strongest statistical relationship was identified between the size of informal employment and the share of households that perceive themselves to be poor (disposable income was again the controlling variable).
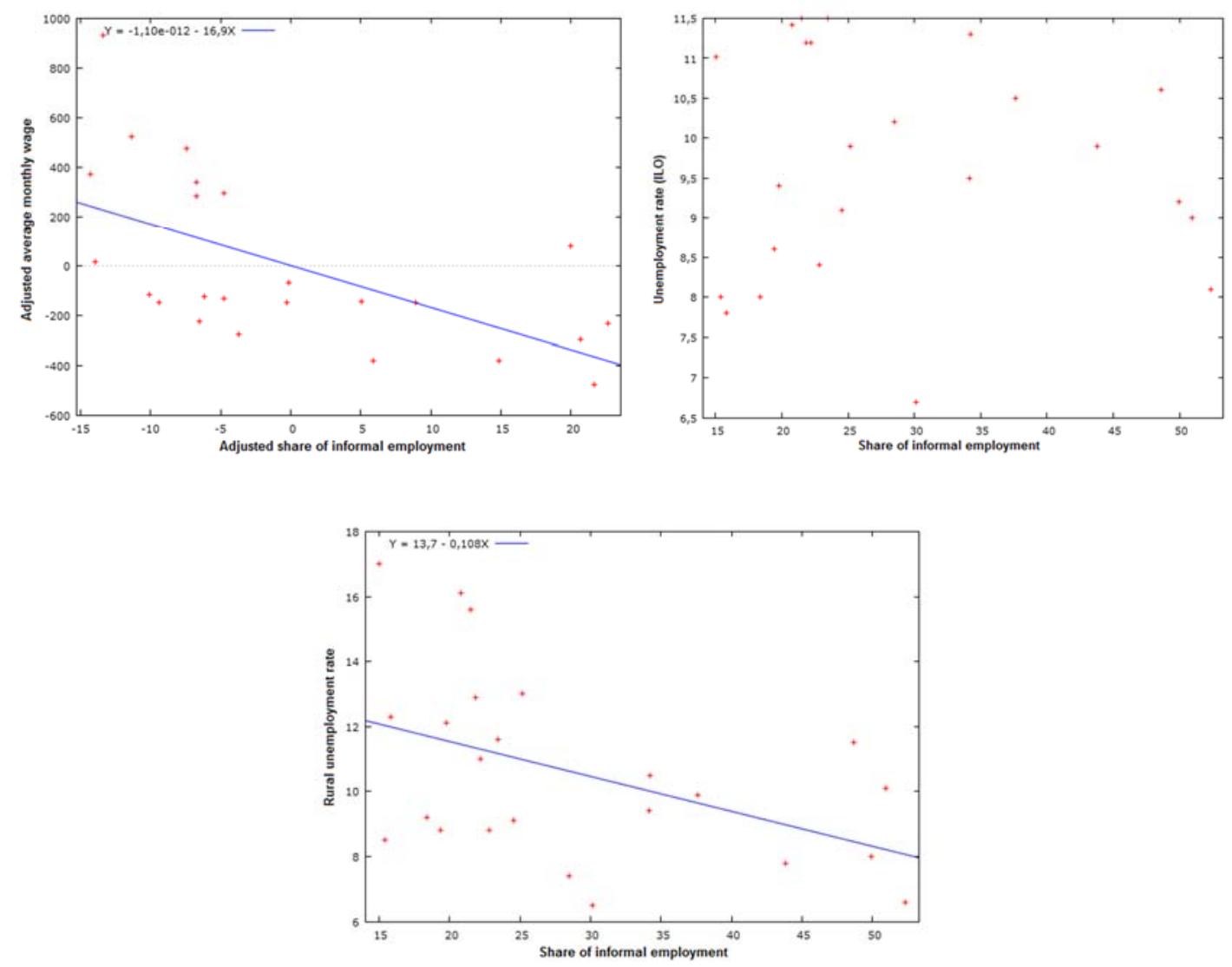

Fig 7. Relationship between the share of informal employment and selected indicators of objective quality of life in 2014 (average monthly wage adjusted according to the rate of unemployment). Source: own elaboration based on data of State Statistics Service of Ukraine (2015)

When correlating the share of informal employment in regional economy and the income level measured as average monthly wage per capita we identified the opposite trend. With increasing share of informal employment in the regions, the income level of population decreases significantly even when we take into consideration the level of unemployment (variables were adjusted according to the rate of unemployment). Several studies also proved the trend of decreasing earning potential of informally employed workers (Zimmermann, 2012). As Chen et al. (2006) stated, households which depend on the most precarious forms of informal employment as their primary source of income are likely to have substantially higher poverty risk than those that have access to more stable and better quality employment. The relationship between the unemployment level and the share of informal employment is not definitive. Taking into account most regions, there is a positive relationship between the rate of unemployment and the share of informal employment. However, some regions exhibit high share of informally employed population and average unemployment rate (namely Chernivtsi and Transcarpatia) and even below average unemployment rate (Ivano-Frankivsk). Odessa region which had the lowest unemployment rate if we do not take into account the cities of Kiev and Sevastopol $(6.7 \%)$ in 2014 , had average share of informally employed (approximately 30\%). These are regions bordering with Hungary, Romania and Slovakia (with simplified border crossing 
procedure for residents of the border area), where large share of population works in the mentioned EU countries. The relationship between the rural unemployment and the share of informally employed population is clearer. It indicates, that regions with higher share of informally employed population in general have lower unemployment rate of rural population. This finding is indicative of the potential of informal employment and informal sector as a viable means of generating job opportunities for rural dwellers.

\section{Conclusions}

The aim of the paper was to determine the relationship between informal economy and level of development and quality of life in Ukrainian regions. We also focused on regional disparities in the share of informal employment in formal and informal enterprises. We have examined household income and living conditions, and labour market in regions of Ukraine. Special attention was paid to informal employment in rural areas.

The decline of economic activity was observed mainly among the dwellers of rural areas in 2008-2014. The employment rate is highest in population aged 35-49. The highest rate of unemployment and, at the same time, highest intensity of informal working activities are characteristic for young people aged 15-24 and people aged 60-70. Significantly higher share of informally employed occurred in rural areas when compared to towns and cities. Even if we consider rural-urban disparities on the regional level, there are statistically significant differences in the size of the informal sector in economies of Ukrainian regions with the highest share of informally employed in the predominantly rural regions. In rural areas of Ukrainian regions, informally employed were mostly those classified under elementary occupations and close to one third of all services and trade personnel, skilled workers in agriculture, forestry and fish farming, and skilled workers using specific tools.

Relatively unfavourable relationship was identified between the level of informal employment and selected indicators of both subjective and objective quality of life in Ukrainian regions. In regions with higher share of informal employment more households tend to identify themselves as poor or otherwise deprived. Not surprisingly, with decreasing level of income measured as average monthly wage, the share of informal employment in regional economies increased. We have not identified definitive relationship between unemployment and informal employment. The key finding in this respect is decreasing rural unemployment in regions with higher shares of informal employment that indicates the potential of informal sector to create job opportunities in rural areas of Ukrainian regions. This, however, does not increase material well-being, when we take into account other findings presented in the paper. These findings confirm results of previous research done by Zimmermann (2012) and Chen et al. (2006) found. Certainly, unemployment is one of the most serious problems in rural regions of the country. If we choose to view informal sector as one of the means of providing rural population with job opportunities, stress must be put on ensuring the higher quality of those jobs and better working conditions of informally employed. Resolving this issue could contribute substantially to stabilization and further development of the Ukrainian countryside.

References

[1] Brown, J. D., Earle, J. S. \& Vakhitov, V. (2006). Wages, layoffs, and privatization: evidence from Ukraine. Journal of Comparative Economics 34(2), 272-294. DOI: $10.1016 / j . j c e .2006 .02 .004$.

[2] Chen, M., Vanek, J. \& Heintz, J. (2006). Informality. Gender and Poverty. A Global Picture. Economic and Political Weekly 41(21), 2131-2139.

[3] D'Agostini, L. R. \& Fantini, A. C. (2008). Quality of Life and Quality of Living Conditions in Rural Areas: Distinctively Perceived and Quantitatively Distinguished. Social Indicators Research 89, 487-499. Doi: 10.1007/s11205-008-9245-4. 
[4] Dohmen, T., Khamis, M. \& Lehmann, H. (2010). Risk Attitudes and the Incidence of Informality among Workers: Evidence from a Transition Country. ESCIRRU Working Papers 22. Berlin: German Institute for Economic Research.

[5] International Labour Organization (ILO). (2004). Final report of the $17^{\text {th }}$ International Conference of Labour Statisticians. Online: http://www.ilo.org/global/statistics-anddatabases/meetings-and-events/international-conference-of-labourstatisticians/WCMS_087568/lang--en/index.htm

[6] International Labour Organization (ILO). (2012). Statistical Update on Employment in the Informal Economy. Geneva.

[7] International Labour Organization (ILO). (2013). Measuring Informality: A Statistical Manual on the Informal Sector and Informal Employment. Geneva.

[8] Ira, V., Michálek, A. \& Podolák, P. (2005). Kvalita života a jej regionálna diferenciácia v Slovenskej republike. Životné prostredie 39(6), 290-294.

[9] Knapik, W. \& Kowalska, M. (2014). Zróżnicowanie obszarów wiejskich w Polsce na tle procesów społeczno-ekonomicznych i demograficznych. Problemy drobnych gospodarstw rolnych. 1, 37-54.

[10] Kowalska, M. \& Puchała, J. (2015). The current social - demographic problems of Poland (pp. 103-110). In Proceedings of IAC-SSaH 2015. Praha: Czech Institute of Academic Education z.s.

[11] Kozelová, D., Mura, L., Gecíková, I. \& Pietrová, M. (2011). The analysis of agrarian employment and labour productivity with the focus on agroturism. Forum statisticum Slovacum 7(7). 97-102.

[12] Kupets, O. (2006). Determinants of unemployment duration in Ukraine. Journal of Comparative Economics 34(2) 228-247. DOI: 10.1016/j.jce.2006.02.006.

[13] Laluha, I., Ošková, S. \& Stanek, V. (2005). Kvalita života, sociálne nerovnosti a diferenciácia obyvatelstva. Sociológia 37(2), 119-142.

[14] Macour, K. \& Swinnen, J. F. M. (2007). Rural Poverty in Transition Countries. LICOS Discussion Papers 169/2007 Leuven: Katholieke Universiteit.

[15] Münich, D., Svejnar, J. \& Terrell, K. (2005). Returns to human capital under the communist wage grid and during the transition to a market economy. Review of Economics and Statistics 87(1), 100-123.

[16] Pantyley, V. (2009). Demographic Situation of Rural Population in Ukraine in the Period of Intensive Socio-Economic Transformation. European Countryside 1(1), 34-52. DOI: 10.2478/v10091-009-0004-6.

[17] Pisarenko, S. (1999). The investigation of the socio-economic development of the countryside in Ukraine. Eastern European Countryside 5, 127-129.

[18] Semenova, T. (2012). New strategies for rural development in the Russian North. European Countryside 4(2), 101-115. DOI: 10.2478/v10091-012-0017-4.

[19] Stiglitz, J., Sen, A. \& Fitoussi, J. P. (2009). Report by the Commission on the Measurement of Economic Perfomance and Social Progress. Retrieved from www.stiglitz-sen-fitoussi.fr.

[20] Thomka, A. (2005). The informal economy and viability of small family farms in Romania. Eastern European Countryside. 11, 89-109.

[21] Zimmermann, K. F. (2012). The precarious new world of "informal jobs". Harvard Business Review November 8, 2012. 